\title{
First Report of Polyplax sp. in a Persian Squirrel (Scuirus anomalus) in Tabriz, Northwest of Iran
}

\author{
Tebriz, Kuzeybatı İran’da, Bir Acem Sincabında (Sciurus anomalus) Polyplax sp. İlk Raporu
}

\author{
Shahrokh Shirazi ${ }^{1}$, Farhad Bahadori², Tayebeh-Sadat Mostafaei ${ }^{3}$, Hooman Ronaghi' \\ 'Department of Pathobiology Science and Research branch, Islamic Azad University, Tehran, Iran \\ ${ }^{2}$ Department of Veterinary Medicine, Islamic Azad University, Tabriz, Iran \\ ${ }^{3}$ Department of Veterinary Parasitology, Faculty of Veterinary Medicine, Urmia University, Urmia, Iran
}

\begin{abstract}
The Persian squirrel (Scuirus anomalus) has a long furry tail, which is longer than half of the body, and lives in the Zagros forest. It is distributed in the west and northeast of Asia. In the summer 2011 a Persian squirrel with signs of hair loss and itch in head and tail was referred to the veterinary clinic. There were arthropods in the lesion in the first survey. Many of these parasites were collected and were sent to Parasitology Laboratory of Science and Research University in Tehran. Samples were processed and were identified according to lices diagnostic keys using a light microscope. Lice that were sent to the national parasitology museum were identified as Polyplax sp. too. (Turkiye Parazitol Derg 2013; 37: 299-301)
\end{abstract}

Key Words: Persian squirrel, lice, infection, Tabriz

Received: 14.02.2013

Accepted: 10.09.2013

\section{ÖZET}

Acem sincabının (Sciurus anomalus) vücudunun yarısından uzun bir tüylü kuyruğu vardır ve Zagros ormanlarında yaşamaktadır. Asya'nın batı ve kuzeydoğusunda yaygındır. 2011 yazında bir Acem sincabı baş ve kuyrukta tüy dökülmesi ve kaşıntı belirtileri ile veteriner kliniğine sevk edildi. Ilk taramada lezyonda artropodlar vardı. Bu parazitlerin çoğu toplandı ve Tahran'daki Bilim ve Araştırma Üniversitesi Parazitoloji laboratuvarına gönderildi. Numuneler işleme alındı ve bir ışık mikroskobu kullanılarak bit teşhis şifrelerine göre tanımlandı. Ulusal parazitoloji müzesine gönderilen bitler de Polyplax sp. olarak tanımlandı. (Turkiye Parazitol Derg 2013; 37: 299-301)

Anahtar Sözcükler: Acem sincabı, bit, enfeksiyon, Tebriz.

Geliş Tarihi: 14.02.2013

Kabul Tarihi: 10.09.2013

\section{INTRODUCTION}

Persian squirrel considered as a pet animal is one of the endemic rodents of Iran. There is a little information about parasitic disease of this animal in Iran.

Persian squirrel is medium size with the length of 20-25 centimeter. It's back hair is brownish gray and is yellow in ventral side. Heads hair and back of the tail is reddish fawn. Red head and tail of Persian squirrel are special features different from other squirrel in Iran.
Moderate forest of some areas in Iran, Armenia, Azerbaijan, Georgia, Greece, Iraq, Jordan, Lebanon, Syria and Turkey are habitat of this animal. Infestation of arthropods such as lice infestation in small rodents has reported from all over the world (1-3). Although there are studies on rodent's parasitic infections in Iran, there are limited studies on the ectoparasitic infestation of squirrel (4-6).

The present study was carried out to determine ectoparasitic infestations in a Persian squirrel.

Address for Correspondence / Yazışma Adresi: Dr. Shahrokh Shirazi, Department of Veterinary Parasitology, Division of Science and Research, Islamic Azad University, Tehran, Iran. Phone: 00989143040387 E-mail: sh.shirazi@srbiau.ac.ir doi:10.5152/tpd.2013.3085 


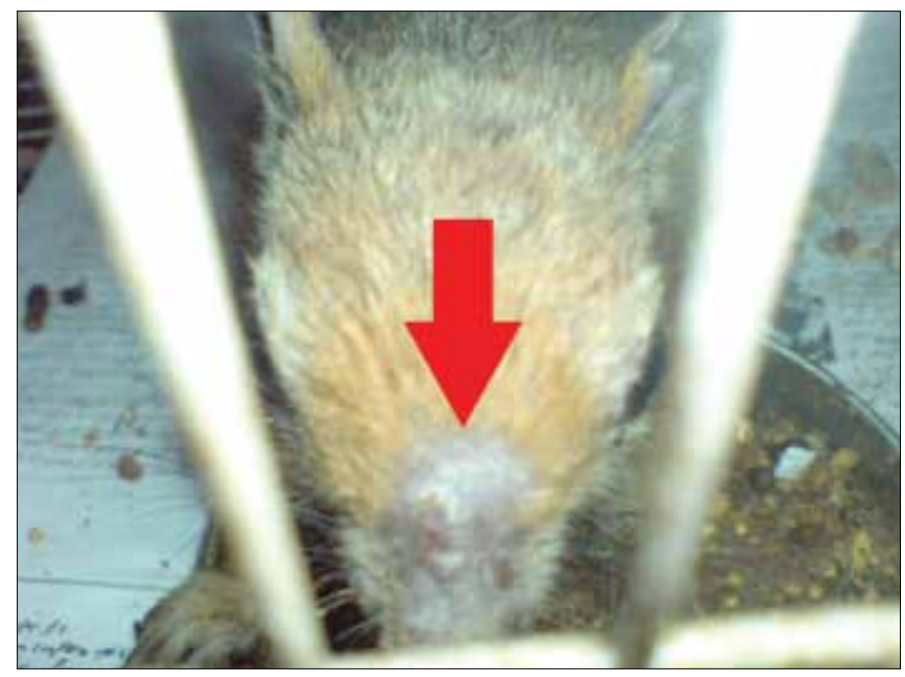

Figure 1. Alopecia on squirrel's muzzle

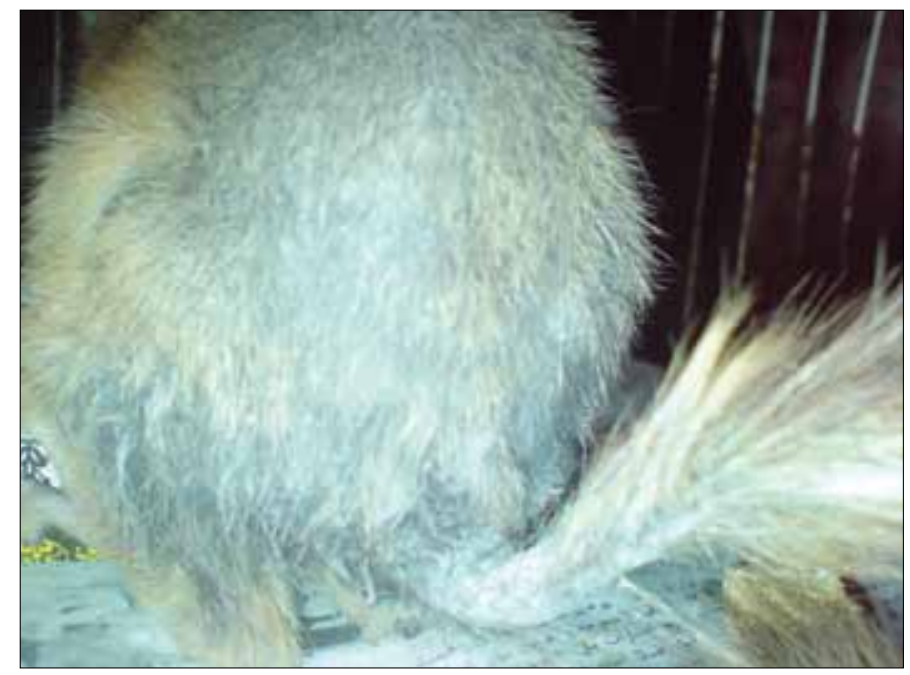

Figure 2. Alopecia on bias of tail

It's needed to release this information because of insufficient information about parasitic infections in wild and domestic squirrel in Iran.

\section{METHODS}

In the summer 2011 a Persian squirrel with signs of hair Loss and itch in head and tail was referred to the veterinary clinic. There were arthropods in the lesion in the first survey (Figure 1, 2). Some of these ectoparasites were collected and were sent to parasitology laboratory of Science and Research University in Tehran. Samples were processed and were identified with a light microscope.

\section{RESULTS}

According to lice diagnostic keys it was found that the lesions were caused by Polyplax and infection by numerous lice were responsible for these lesions (7). Lice were sent to the national parasitology museum in order to final diagnosis and samples were identified as Polyplax too (Figure 3). This is the first report of squirrel's infestation by Polyplax in East Azerbaijan province of Iran.

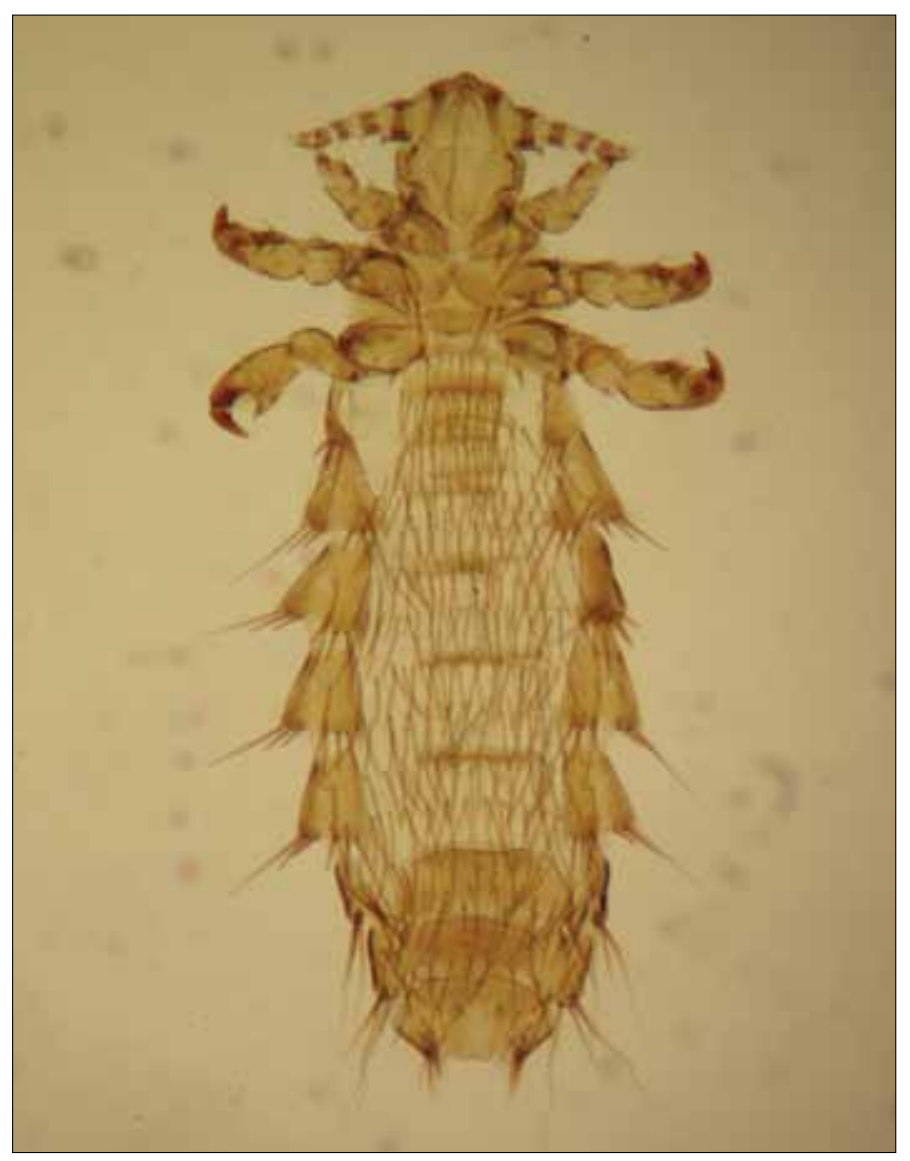

Figure 3. Polyplax founded on Persian squirrel

\section{DISCUSSION}

Polyplax is belonging to malophaga that cause irritation, anxiety and scrape. Anemia, weakness and even die would happen due to super infection. And also it has a role in pathogenic microorganism's transmission $(8,9)$.

Polyplax serrate and $P$. spinulosa are common cause of pediculosis the laboratory mouse and laboratory rat respectively. They have slender bodies, 0.6-1.5mm long, yellowish-brown. The average of life cycle is 13 days for $P$. serrata and 25 to 28 days for $P$. spinulosa. Both are vectors of various organisms. Thus $P$. spinulosa transmits Haemobartonella and $P$. serrata transmits $E$. perythrozoon and Francisella species (10).

Nowadays squirrel is considered as a pet animal, so identify their disease especially parasitic disease seems important. According to internal researches, there are some studies on parasitic infections in squirrel while many studies have done by foreign researchers. Rasouli in 2011 reported 8\% infestation by Polyplax in laboratory rats of Urmia University (6). In a study in Lorestan (2005) infestation by lice has been reported in rodents but they were silent about the genus of them (5). In 2006, different genus of lice were reported in domestic squirrel in Tehran but none of them were Polyplax (11). Studies have been done on parasitic infection in squirrel in many countries such as Turkey $(12,2,13)$. A lot of studies have done in small rodents such as squirrel (14). Bittencourt in 2003 has studied on infection of small mammals of Brazilian rain forest and he has reported the infestation by 
Polyplax in squirrel that is consistent with this survey (1). Lice infestation in 11/9\% rodents of Malaysia was reported in 2006 by Paramasvaran and there was Polyplax among reported lice (15). In 1996 Coyner reported infestation by lice in squirrel in Florida but none of them were Polyplax (16). In Japanese squirrel infection by anoplora and malophaga has been reported (3). Soliman reported lice infestation in 32/9\% rats of Egypt and also there was polyplax (17).

According to the importance of this arthropod in rodent health especially wild and domestic squirrel it's suggested to do more research in this field.

\section{CONCLUSION}

Beside our findings, among the countries that have done study on squirrel, only Brazilian researchers have reported Polyplax in these kinds of animals, but in Iran and the other countries there are report of Polyplax contamination in others rodents such as rat.

Conflict of Interest: No conflict of interest was declared by the authors.

Interest: The authors declared that this study has received no financial support.

Peer-review: Externally peer-reviewed.

Informed Consent: Written informed consent was obtained from patients who participated in this case.

Author Contributions: Concept - S.S., F.B.; Design - S.S., H.R.; Supervision - S.S., F.B.; Funding - S.S., H.R.; Materials - S.S., F.B.; Data Collection and/or Processing - S.S., T.M.; Analysis and/or Interpretation - S.S., H.R.; Literature Review - S.S., F.B.; Writing S.S., T.M.; Critical Review - S.S., F.B.; Other - S.S., T.M.

Acknowledgements: The authors thank Department of Environment of East Azerbaijan especially Dr. Biuk Reiisi as a manager and Dr. Hosaini Comi as a wildlife expert and also thank Dr. Iraj Mubedi manager of national parasitology museum of Iran.

Çıkar Çatışması: Yazarlar çıkar çatışması bildirmemişlerdir.

Finansal Destek: Yazarlar bu çalışma için finansal destek almadıklarını beyan etmişlerdir.

Hakem değerlendirmesi: Dış bağımsız.

Hasta Onamı: Yazılı hasta onamı bu olguya katılan hastalardan alınmıştır.

Yazar Katkıları: Fikir - S.S., F.B.; Tasarım - S.S., H.R.; Denetleme - S.S., F.B.; Kaynaklar - S.S., Malzemeler - S.S., F.B.; Veri toplanması ve/veya işlemesi - S.S., T.M.; Analiz ve/veya yorum - S.S., H.R.; Literatür taraması - S.S., F.B.; Yazıyı yazan - S.S., T.M.; Eleştirel İnceleme - S.S., F.B.; Diğer - S.S., T.M.

Teşekkür: Yazarlar Doğu Azerbaycan Çevre Bakanlığına, müdür Dr. Biuk Reiisi'ye, vahşi yaşam uzmanı Dr. Hosaini Qomi'ye ve
Ulusal Parazitoloji Müzesi Müdürü Dr. Iraj Mubedi'ye teşekkür ederler.

\section{REFERENCES}

1. Bittencourt EB, Rocha CF. Host-ectoparasite Specificity in a Small Mammal Community in an Area of Atlantic Rain Forest (Ilha Grande, State of Rio de Janeiro), Southeastern Brazil. Mem Inst Oswaldo Cruz 2003; 98: 793-8. [CrossRef]

2. Özmen Ö, Yukari BA and Haligur M. First report of Eimeria lancasterensis in a Red Squirrel (Sciurus vulgaris L.) in Turkey. Türkiye Parazitoloji Dergisi 2009; 33: 245-7.

3. Shinozaki Y, Shiibashi T, Yoshizawa K, Murata K, Kimura J, Maruyama $\mathrm{S}$ and et al. Ectoparasites of the Pallas squirrel, Callosciurus erythraeus, introduced to Japan. Med Vet Entomol 2004; 18: 61-3. [CrossRef]

4. Fallah E, Farshchian M, Mazlomi A, Majidi J, Kusha A, Mardi A, et al. Study on the prevalence of Visceral Leishmaniasis in rodent of Azarshahr dstrict (new focus), northwest of Iran. Archives of Razi Institute 2007; 61: 27-33.

5. Rafinejad J, Asghari Sh, Tigari S, Basseri H and Nikpour F. Parasitic Arthropods of Rodents in Khorramabad-Lorestan, Iran. Proceedings of the Fifth International Conference on Urban Pets, Malaysia 2005; 363-9.

6. Rasouli S, Tehrani A, Hifian H, Athayi M, Ghafarzadeh S, Pirbudaghi $\mathrm{H}$, et al. A report over the infection with the louse Polyplax spinulosa in typical rats belonging to the wistar strain kept in the laboratory animal breeding and keeping Center of Urmia University. Global Veterinaria 2011; 6: 547-50.

7. Hopla CE, Durden LA and Keirans JE. Ectoparasites and classification. Rev Sci Tech 1994; 13: 985-1017.

8. Foreyt WJ. Veterinary Parasitology: Reference Manual. Fifth Edition Lowa State University: Blackwell Publishing; 2001.

9. Wall R and Shearer D. Veterinary Ectoparasites: Biology, Pathology and Control. Second Edition. London: Blackwell Science; 2001. [CrossRef]

10. Soulsby, E.J.L. Helminthes, Arthropods and Protozoa of Domesticated Animal. 7th Edition, London: Bailliere Tindall: 1986.

11. Sakhaee M. Study on Internal and External parasites of pet Persian Squirrel (Scuirus anomalus) referred to Tehran university small animal hospital. The thesis of degree Doctor of Philosophy in Veterinary Parasitology, Faculty of Sciences, University of Tehran, Iran. 2006.

12. Çiçek H, Karatepe M, Karatepe B, Cakir M and Eser M. Eimeria species (Apicomplexa: Eimeriidae) detected from the Anatolian ground Squirrel, Spermophilus xanthophrymnus (Rodentia:Sciuridae) in Niğde province, Turkey. Ankara Üniv Vet Fak Derg 2010; 57: 143-4. [CrossRef]

13. Uslu U, Dik B and Gökçen A. Ectoparasites of the ground squirrel (Citellus citellus (L.)) in Turkey. Turkiye Parazitol Derg 2008; 32: 142-5.

14. Lainson R, Brigido M and Silveira FT. Blood and Intestinal Parasites of Squirrels in Amazonian Brazil. Mem Inst Oswaldo Cruz 2004; 99 : 577-9. [CrossRef]

15. Paramasvaran S, Sani RA, Hassan L, Krishnasamy M, Jeffery J, Oothuman $\mathrm{P}$, et al. Ectoparasite fauna of rodents and shrews from four habitats in Kuala Lumpur and the states of Selangor and Negeri Sembilan, Malaysia and its public health significance. Trop Biomed 2009; 26: 303-11.

16. Coyner DF, Wooding JB and Forrester DJ. A Comparison of Parasitic Helminths and Arthropods From Two Subspices of Fox Squirrels (sciurus niger) in Florida. J Wildl Dis 1996; 32: 492-7. [CrossRef]

17. Soliman S, Main AJ, Marzouk AS and Montasser AA. Seasonal studies on commensal rats and their ectoparasites in a rural area of Egypt: the relationship of ectoparasites to the species, locality, and relative abundance of the host. J Parasitol 2001; 87: 545-53. [CrossRef] 